work of the Irish Sea Fisheries Association, Ltd., which began to function in 1931, and during the period intervening was engaged in the provision and equipment, on hire-purchase terms, of more than 130 motor-vessels which constitute the bulk of the existing fishing fleet. The larger landings in the year are attributable mainly to the efforts of the inshore fishermen, who found themselves well equipped at the onset of war conditions which have caused such a radical change in the operation of supply and demand for the output of sea-fishing in common with other food-producing industries. The increased earnings now obtainable are attracting more and more men.

The Dingle fishermen again did remarkably well, and their landings were just double the value of those of the preceding year. The summer and winter herring fishery, contrasted with 1939 , showed quantitative increases of 21 per cent and 56 per cent respectively. The catches of salmon and sea-trout are better than those of the three preceding seasons, but are still below the average for the previous four decades. The drift-net fishings for salmon off the north and north-west coasts were also below average. The spawning season was a good one in nearly all fishing districts and the run of smolts, so far as was ascertainable, up to the average of previous years. The bad weather, however, interfered seriously with hatching experiments, although the output from the experimental brown trout hatchery at Lough Owel was nevertheless the highest yet recorded.

\section{Meteorology in Iraq}

The fifth annual report of the Director of the Meteorological Service of the Government of Iraq, which covers the year ending March 31, 1941, describes the work of this Service during a period when it was much affected by the entry of Italy into the War on June 10, 1940. The amount of civil aviation in Iraq was greatly reduced, but the companies still carrying on were supplied with reports and forecasts on the usual lines. The greatest difficulties arising from the entry of Italy into the War were in connexion with supplies of equipment from Great Britain. The supply of balloons required for making observations of the upper winds became erratic, and larger reserves had to be built up, which gave rise to problems of storage in a climate very unfavourable for rubber storage. The experiment was made of getting balloons made in Australia and the United States. In both cases results were satisfactory apart from the extra expense.

Other innovations included the making of the hydrogen required for the balloons on the spot with the aid of French generators employing ferro-silicon, and the construction by the Ordnance Department of Stevenson screens and rain-gauges, the former at a cost less than half that involved when obtaining the screens from England. What is described as the outstanding event of the year under review was the setting up of synoptic reporting stations at Hail and Riyadh in Saudi Arabia with the help of King Ibn Saud. A new observatory was also established at Kut al Hai, and a Dines pressure tube anemometer was installed at Rutba at considerable expense. A beginning was made with the preparation for publication of all available climatological data based on observations made in Iraq. The report, therefore, shows that the year was one of progress in spite of the unusual difficulties in the way of advance.

\section{The Ray Society}

The report of the Council of the Ray Society, which has just been circulated, states that, with the consent of the members, the annual general meeting has again not been held, and the present officers and council will continue to act for the current year. The accounts show that the reduction in the amount received from subscriptions has again been less than was anticipated and the sales of the Society's publications have been well maintained. A volume on "The Larvæ of Decapod Crustacea" by Dr. Robert Gurney will shortly be issued to subscribers for 1941. A work on the British Mysidæ (Opossum shrimps) by Prof. W. M. Tattersall is in preparation and is intended to form the issue for 1942. Owing to shortage of materials, the publications will, for the present, be issued in paper covers, but it is hoped later to supply covers for binding uniform with the volumes already published. The Council reminds members that, under present conditions, considerable delay in the publication of the annual volumes cannot be avoided. It is mentioned that at least one author has lost, by enemy action, all the notes and manuscripts prepared for a work to be offered to the Society.

\section{Diseases and War}

THE April issue of the Quarterly Review contains an interesting article on this subject by Major Frederic Evans, who discusses the problems of an army so far as the maintenance of health is concerned. $\mathrm{He}$ classifies the diseases which it is important to prevent in the following nine groups: (1) louseborne diseases, which consist of typhus fever, trench fever and relapsing fever, (2) mosquito-borne diseases, namely, malaria and yellow fever, (3) diseases caused by sandflies in hot regions, such as sandfly fever, oriental sore and probably kala-azar, (4) excremental diseases, namely, typhoid, paratyphoid, cholera, dysentery and infectious diarrhœea, (5) diseases due to droplet infection, such as cerebro-spinal fever, diphtheria, scarlet fever, measles, smallpox, influenza and pulmonary tuberculosis, (6) venereal diseases and skin diseases, especially scabies, (7) diseases caused by environmental conditions, namely, heat stroke, frostbite and trench foot, and (8) food deficiency diseases, such as scurvy, beriberi and night-blindness. In conclusion, Major Evans emphasizes the importance of the medical officer training his sanitary duty squad as thoroughly as he trains his stretcher bearers and medical orderlies.

\section{The Far East and the War}

Prof. P. M. RoxBy's admirable pamphlet on "China" (Oxford Pamphlets on World Affairs, No. 54. London: Oxford University Press. 4d. net) provides an excellent introduction, for those who have only now come to realize the importance of China in the War, to an understanding of the place of China in the struggle of the United Nations. Within the compass of thirty pages, he gives a succinct description of the land of China, the impact thereon of the West, and of the Nationalist movement and the progress of reconstruction up to 1931. The latter part of the pamphlet deals with the Japanese seizure of Manchuria and the consequences of the Sino-Japanese war which broke out in 1937. With Sir John Pratt's "Japan and the Modern World" (Oxford Pamphlets on World Affairs, No. 55. 4d. net) a penetrating analysis is afforded 